Prepared in cooperation with the U.S. Army Corps of Engineers

\title{
Investigation of Methods for Successful Installation and Operation of Juvenile Salmon Acoustic Telemetry System (JSATS) Hydrophones in the Willamette River, Oregon, 2012
}

Open-File Report 2014-1112 



\section{Investigation of Methods for Successful Installation and Operation of Juvenile Salmon Acoustic Telemetry System (JSATS) Hydrophones in the Willamette River, Oregon, 2012}

Gary L. Rutz, Matthew D. Sholtis, Noah S. Adams, and John W. Beeman

Prepared in cooperation with the U.S. Army Corps of Engineers

Open-File Report 2014-1112

U.S. Department of the Interior

U.S. Geological Survey 


\section{U.S. Department of the Interior SALLY JEWELL, Secretary}

\section{U.S. Geological Survey \\ Suzette M. Kimball, Acting Director}

U.S. Geological Survey, Reston, Virginia: 2014

For more information on the USGS-the Federal source for science about the Earth, its natural and living resources, natural hazards, and the environment-visit http://www.usgs.gov or call 1-888-ASK-USGS

For an overview of USGS information products, including maps, imagery, and publications, visit http://www.usgs.gov/pubprod

To order this and other USGS information products, visit http://store.usgs.gov

Suggested citation:

Rutz, G.L., Sholtis, M.D., Adams, N.S., and Beeman, J.W., 2014, Investigation of methods for successful installation and operation of Juvenile Salmon Acoustic Telemetry System (JSATS) hydrophones in the Willamette River, Oregon, 2012: U.S. Geological Survey Open-File Report 2013-1112, 18 p.,

http://dx.doi.org/10.3133/ofr20141112.

ISSN 2331-1258 (online)

Any use of trade, firm, or product names is for descriptive purposes only and does not imply endorsement by the U.S. Government.

Although this information product, for the most part, is in the public domain, it also may contain copyrighted materials as noted in the text. Permission to reproduce copyrighted items must be secured from the copyright owner. 


\section{Contents}

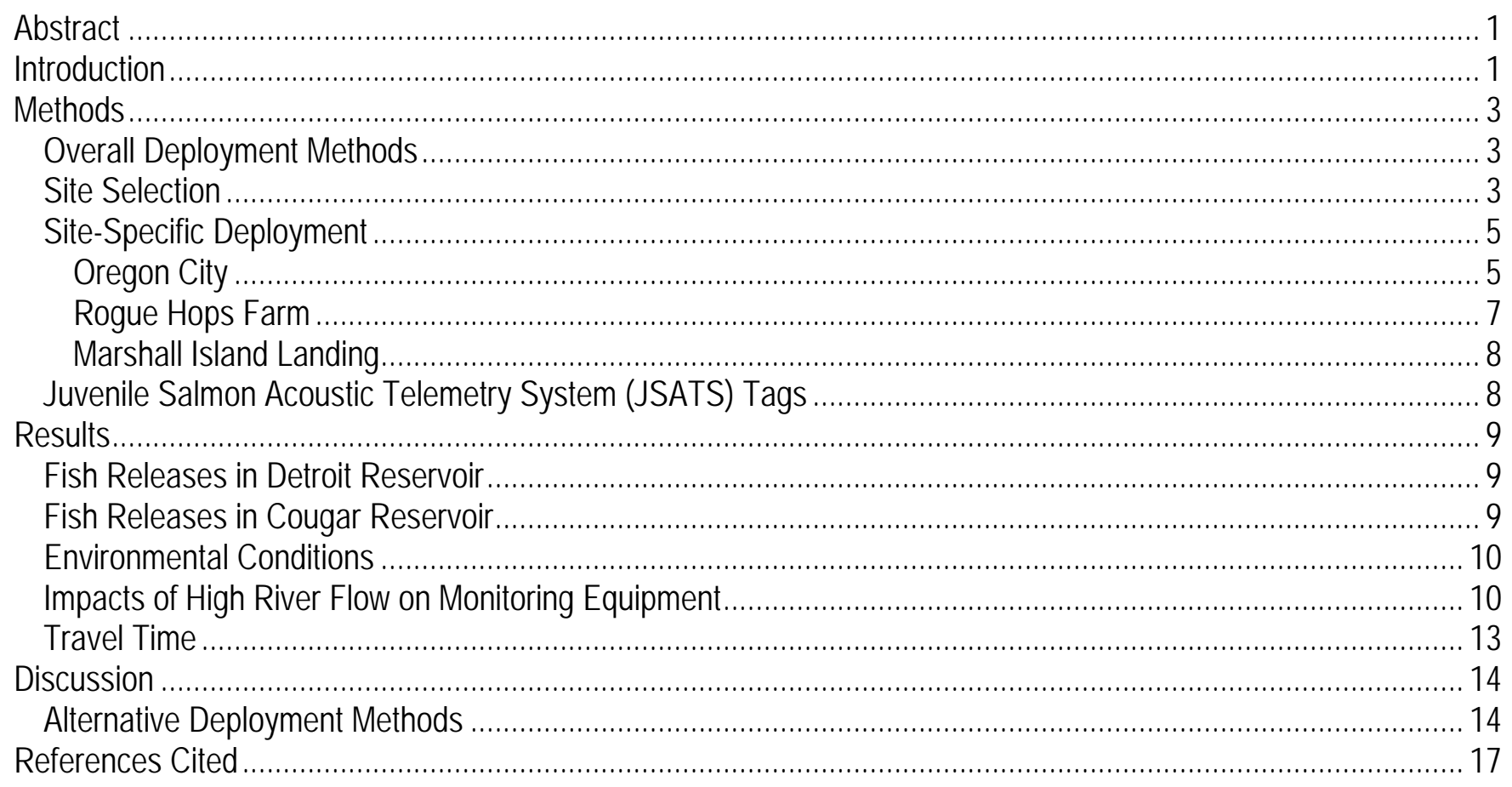

\section{Figures}

Figure 1. Schematic showing the Willamette Valley showing three locations where Juvenile Salmon Acoustic Telemetry System (JSATS) equipment was installed in the Willamette River, Oregon, fall 2012. ............................ 4 Figure 2. Photograph showing mount used to deploy Juvenile Salmon Acoustic Telemetry System (JSATS) hydrophones in the Willamette River, Oregon, 2012.

Figure 3. Photograph showing hydrophone cable connection using wire mesh cable grips and 12.7-mm shackle used in 2012.

Figure 4. Schematic showing hydrophone locations installed at the Oregon City, Oregon site (river kilometer 41), 2012

Figure 5. Schematic showing hydrophone locations at the Rogue Hops Farm site (river kilometer 165.5), Oregon, 2012.

Figure 6. Schematic showing hydrophone locations at the Marshall Island Landing site (river kilometer 272), Oregon, 2012..... 8

Figure 7. Hydrograph showing Willamette River discharge near the Oregon City, Oregon site ............................ 10

Figure 8. Hydrograph showing Willamette River discharge near the Rogue Hops Farm site................................ 11

Figure 9. Hydrograph showing Willamette River discharges near the Marshall Island Landing site....................... 12

Figure 10. Graph showing travel time (in days) from the last reservoir detection to the first detection

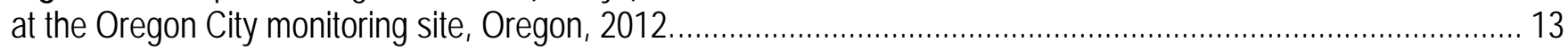

Figure 11. Photograph of Union Street Bridge in Salem, Oregon, 2012 …................................................. 15

Figure 12. Schematic showing a cross sectional view of a bridge support with proposed installation of monitoring equipment 


\section{Tables}

Table 1. Summary statistics of fork length (millimeters) and weight (grams) of acoustic and passive integrated transponder (PIT)-tagged hatchery Chinook salmon at Detroit Reservoir, Oregon, fall 2012

Table 2. Summary statistics of fork length (millimeters) and weight (grams) of acoustic and passive integrated transponder (PIT)-tagged hatchery and wild Chinook salmon at Cougar Reservoir, Oregon, fall 2012

\section{Conversion Factors}

\begin{tabular}{lcl}
\hline Multiply & By & To obtain \\
\hline & Length & \\
\hline foot $(\mathrm{ft})$ & 0.3048 & meter $(\mathrm{m})$ \\
mile $(\mathrm{mi})$ & 1.609 & kilometer $(\mathrm{km})$ \\
\hline & Area & \\
\hline cubic foot $\left(\mathrm{ft}^{3}\right)$ & Volume & \\
\hline & 0.02832 & cubic meter $\left(\mathrm{m}^{3}\right)$ \\
\hline cubic foot per second $\left(\mathrm{ft}^{3} / \mathrm{s}\right)$ & Flow rate & \\
\hline
\end{tabular}

\section{Abbreviations and Acronyms}

JSATS

PIT

rkm
Juvenile Salmon Acoustic Telemetry System

Passive Integrated Transponders

River kilometer 


\title{
Investigation of Methods for Successful Installation and Operation of Juvenile Salmon Acoustic Telemetry System (JSATS) Hydrophones in the Willamette River, Oregon, 2012
}

By Gary L. Rutz, Matthew D. Sholtis, Noah S. Adams, and John W. Beeman

\begin{abstract}
Acoustic telemetry equipment was installed at three sites in the Willamette River during October 2012 to test the effectiveness of using the Juvenile Salmon Acoustic Telemetry System to monitor the movements of fish in a high-flow, high-velocity riverine environment. Hydrophones installed on concrete blocks were placed on the bottom of the river, and data cables were run from the hydrophones to shore where they were attached to anchor points. Under relatively low-flow conditions (less than approximately 10,000 cubic feet per second) the monitoring system remained in place and could be used to detect tagged fish as they traveled downstream during their seaward migration. At river discharge over approximately 10,000 cubic feet per second, the hydrophones were damaged and cables were lost because of the large volume of woody debris in the river and the increase in water velocity. Damage at two of the sites was sufficient to prevent data collection. A limited amount of data was collected from the equipment at the third site. Site selection and deployment strategies were re-evaluated, and an alternate deployment methodology was designed for implementation in 2013.
\end{abstract}

\section{Introduction}

Mark-recapture methods are commonly used to estimate a variety of population parameters (including the timing and success of migration), dam passage probabilities, and in-river survival (Burnham and others, 1987; Williams and others, 2001; Perry and others, 2010). Marks identifying individual animals are often the most useful for such studies, and include passive integrated transponder (PIT) tags and active telemetry systems, such as radio or acoustic telemetry. Under appropriate conditions, active telemetry systems have larger detection ranges and higher detection probabilities than passive systems such as PIT tags, and some offer transmitter positioning capabilities (Adams and others, 2012). For these reasons, active telemetry is commonly used for such studies within the Columbia River Basin to study juvenile salmonids and other fishes.

Recent studies funded by the U.S. Army Corps of Engineers have relied almost exclusively on the Juvenile Salmon Acoustic Telemetry System (JSATS) as the active transmitter technology. The JSATS system was developed by the U.S. Army Corps of Engineers several years ago (McMichael and others, 2010). It is an acoustic telemetry system operating at a frequency of $416.7 \mathrm{KHz}$ and is based on design specifications provided by the U.S. Army Corps of Engineers. Procurement is through an openmarket process, so a variety of manufacturers have produced the equipment. The JSATS family of receiving equipment includes one system based on independent (autonomous) hydrophones and another 
based on hydrophones connected to a central computer with cables. The latter system uses a common time signature enabling positioning of transmitters based on hydrophone position and time-of-arrival of the transmitter pulses. The current transmitters are among the smallest available, with a dry weight in air of $0.3 \mathrm{~g}$. There are ongoing studies based on this system at several Columbia River and Snake River dams, Cougar and Detroit Reservoirs, and elsewhere.

Acoustic telemetry generally performs poorly in shallow, turbulent waters, and best in the opposite conditions. Detection range is primarily dependent on spreading loss and distortion as the signal travels through the water and the noise levels at the receiver (Pincock and Johnston, 2012). Sources of noise at the receiver include acoustic noise from bed movement, wave action, and water current. Additionally, entrained air, vegetation, suspended sediment, and reflections from surfaces, such as the river bottom or the air-water interface, can act to further reduce the effectiveness of acoustic telemetry systems. Each of these conditions may be present to varying degrees in the Willamette River and its tributaries. Thus, it was necessary to carefully select deployment areas after consideration of these factors and to choose a deployment method (type and arrangement of hydrophones) that increased the likelihood of recording transmissions from the acoustic transmitters. Even changes to the pattern of deployment within the same site can affect detection probabilities (Clements and others, 2005). These questions were addressed in this study.

Sources of noise can mimic the signal from valid transmitters and result in false-positive detections that must be reduced or eliminated prior to making inferences from the data (Beeman and Perry, 2012). False-positive detections are present in all active telemetry systems and are often most prevalent in acoustic systems. Common sources are multipath from reflective surfaces, ambient noise, and interference or collisions of signals from more than one transmitter. The probability of false positives depends on many factors, including the physical environment, the numbers of transmitters simultaneously present at a telemetry receiver, how the data are transmitted, and how the transmission is assigned to an individual animal. The probability of accepting false-positive records may be reduced prior to or after the data are recorded. In the JSATS system, false positives recorded by the receivers are reduced through a series of software filters applied to the recorded data (McMichael and others, 2010). One set of filters is applied to data from single autonomous receivers (recall that these have independent clocks and are not synchronized among units) and another is applied to the time-synchronized cabledhydrophone system. This distinction is important to the use of hydrophones in the Willamette River, because the potential for high water velocities and high migration rates of tagged fish reduces the probability of detecting a transmission within the detection range of single hydrophone. One solution is to use multiple hydrophones to form a larger detection area. This seems obvious, but autonomous hydrophones typically have been used in isolation from one another (including the data filtering method), owing to the variation in time keeping among hydrophones. Using multiple autonomous hydrophones as a single detection area will entail either using a different data filter algorithm than the ones used presently, or synchronizing the clocks of multiple autonomous hydrophones and using one of the existing algorithms. Another solution is to use the cabled-hydrophone system in the river. For this study, we chose to use a combination of autonomous nodes with single hydrophones and a cabled array with multiple hydrophones connected to a single receiver.

The objective of this study was to investigate methods for the successful detection of acoustictagged fish in the Willamette River. The short-term goal was to locate sites, install and test equipment, and detect fish carrying JSATS tags from the studies at Cougar and Detroit Reservoirs. The long-term goal is to develop methods suitable for detection of any JSATS-tagged fish in the Willamette River. These data could be used to estimate timing, migration rates, and survival of JSATS-tagged fish from a variety of studies. 


\section{Methods}

\section{Overall Deployment Methods}

Several deployment methods were considered prior to installing the equipment. Acoustic signals do not cross the air-water interface, so hydrophones used to 'hear' the tags must be installed underwater (Pincock and Johnston, 2012). The primary concerns when installing in-water equipment are personal safety during installation, maintenance, removal, and equipment condition during the deployment period. The first choice of deployment method was to drive piles into the riverbed, affix the hydrophones to the piles, and run the cable to a receiver platform atop the pile. This type of deployment has been used successfully in the Columbia and Sacramento Rivers. However, concerns about the short timeline for deployment, acquisition of the necessary permits, and the potential hazard the piles might pose to other river users, an alternative deployment was used. The alternative deployment consisted of hydrophones affixed to anchors placed at the river bottom with cables running to the receivers on shore.

Three monitoring sites were installed in the Willamette River in October 2012 (fig. 1). Each monitoring site consisted of four to six hydrophone mounts that were lowered to the bottom of the river from a boat. The mounts were spaced $50 \mathrm{~m}$ apart and 10-50 m from shore, depending on depth and bathymetry of the river. Each hydrophone mount had one beacon transmitter (to monitor system function) and either one or two hydrophones attached to a $40.8 \mathrm{~kg}$ concrete block weighted with an $18.14 \mathrm{~kg}$ steel weight (fig. 2). Beacon transmitters and hydrophones were securely attached to steel embedded in the concrete using stainless steel hose clamps. All hydrophones transmitted received signals to a shore-based receiver using armored hydrophone cables that were laid on the river bottom and secured to a tree or other available structure on shore using stainless steel wire mesh cable grips (Kellems Grip), 6.35-mm diameter wire rope, and wire rope clips. When multiple lengths of hydrophone cable were required to reach from the hydrophone to the receiver, we secured each connector junction using wire mesh cable grips on each cable end and connected them together using a 12.7-mm diameter steel shackle (fig. 3). To prevent the pin from becoming dislodged from the shackle, a strand of wire was wrapped around the shackle and shackle pin. Cable ends at each mount were anchored to the steel embedded in the concrete mount using wire mesh cable grips and 12.7-mm diameter steel shackles. To provide an additional strength member and to aid in deployment and retrieval of the mount, we added a length of 6.35-mm diameter wire rope between each mount and the shore. The wire rope was connected

to the steel embedded in the concrete by wrapping it around the steel and securing the wire rope to itself with wire rope clips. The wire rope was attached to shore using the same method as the hydrophone cables. The receivers were housed inside a locked steel box that was secured to trees using 6.35-mm diameter wire rope with swaged eyes on each end connected with a lock.

\section{Site Selection}

We selected three sites to test the feasibility of detecting JSATS-tagged fish. We chose a site near the mouth of the McKenzie River (hereafter referred to as the Marshall Island site; river kilometer [rkm] 272), a site near the mouth of the Santiam River (hereafter referred to as the Rogue Hop Farm site; rkm 165.5), and a site downstream of Willamette Falls (hereafter referred to as the Oregon City site; rkm 41). These sites were selected because the river was relatively wide and deep, which would likely minimize damage to equipment as total river discharge increased. 


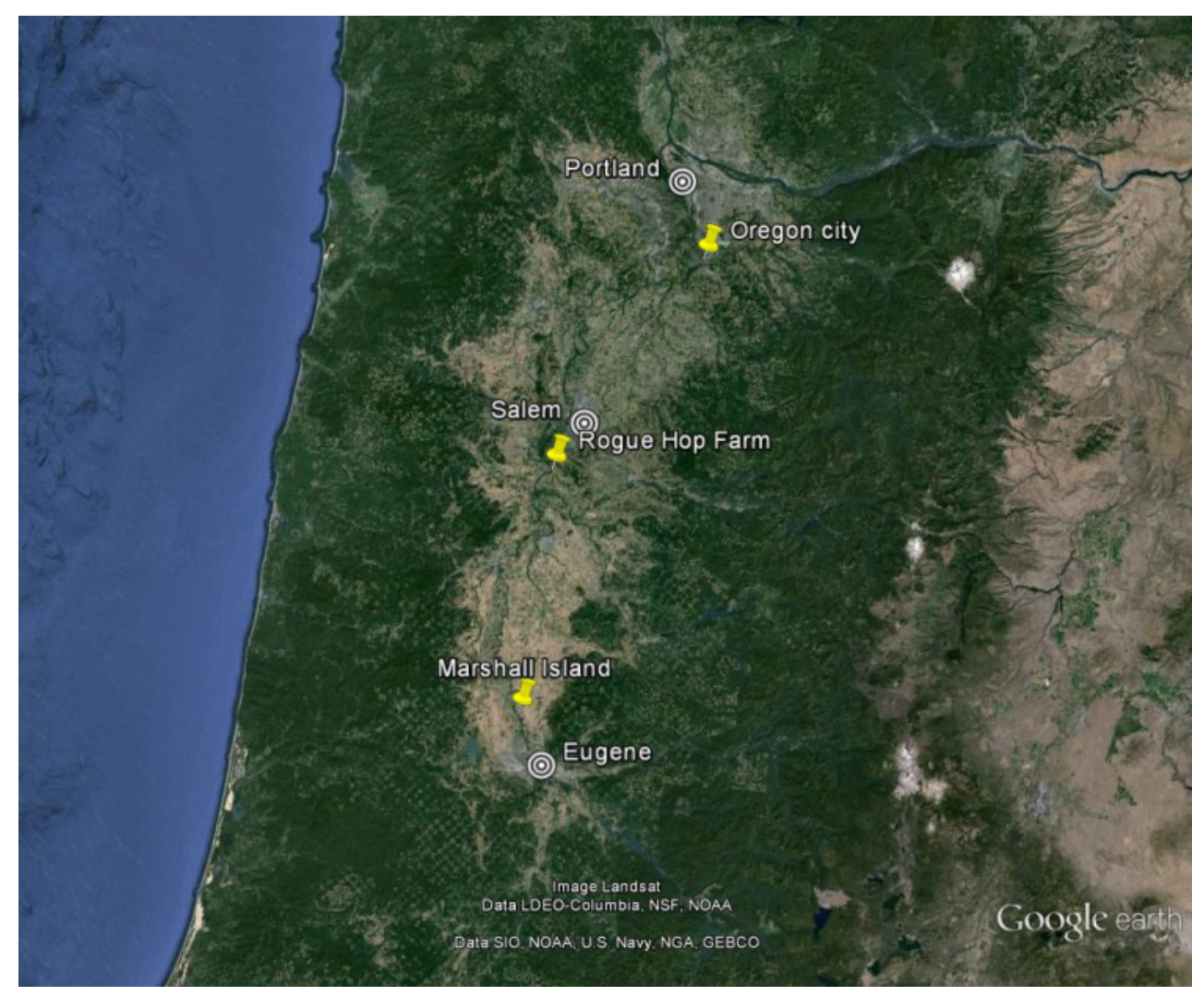

Figure 1. Schematic showing the Willamette Valley showing three locations where Juvenile Salmon Acoustic Telemetry System (JSATS) equipment was installed in the Willamette River, Oregon, fall 2012.

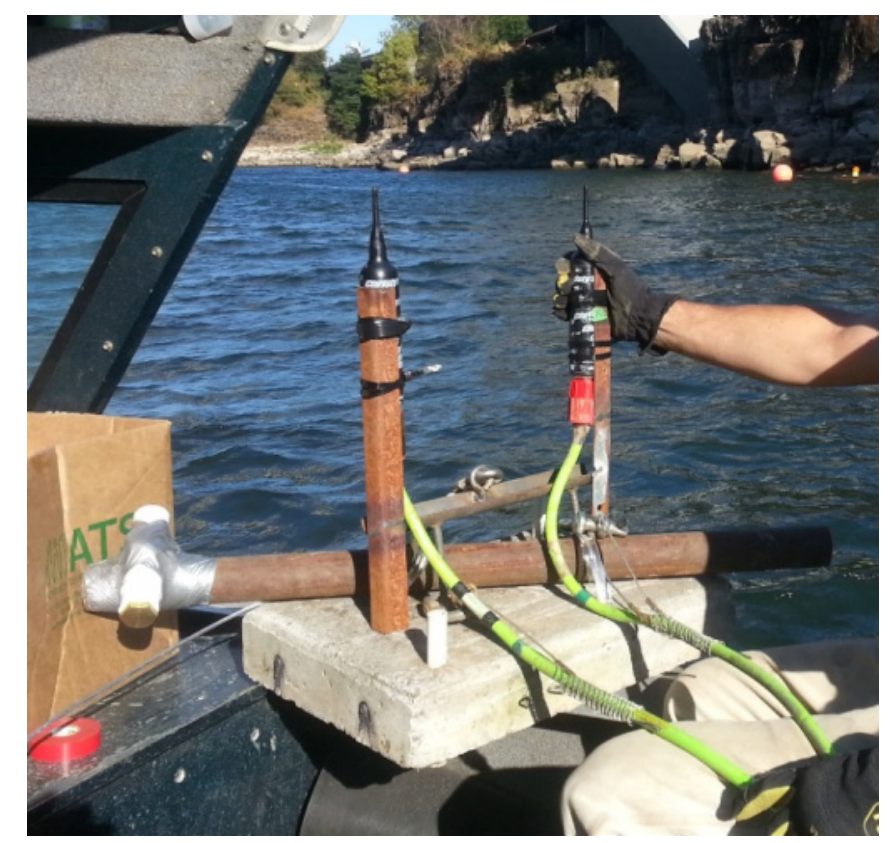

Figure 2. Photograph showing mount used to deploy Juvenile Salmon Acoustic Telemetry System (JSATS) hydrophones in the Willamette River, Oregon, 2012. Photograph taken by Scott Evans, U.S. Geological Survey. 


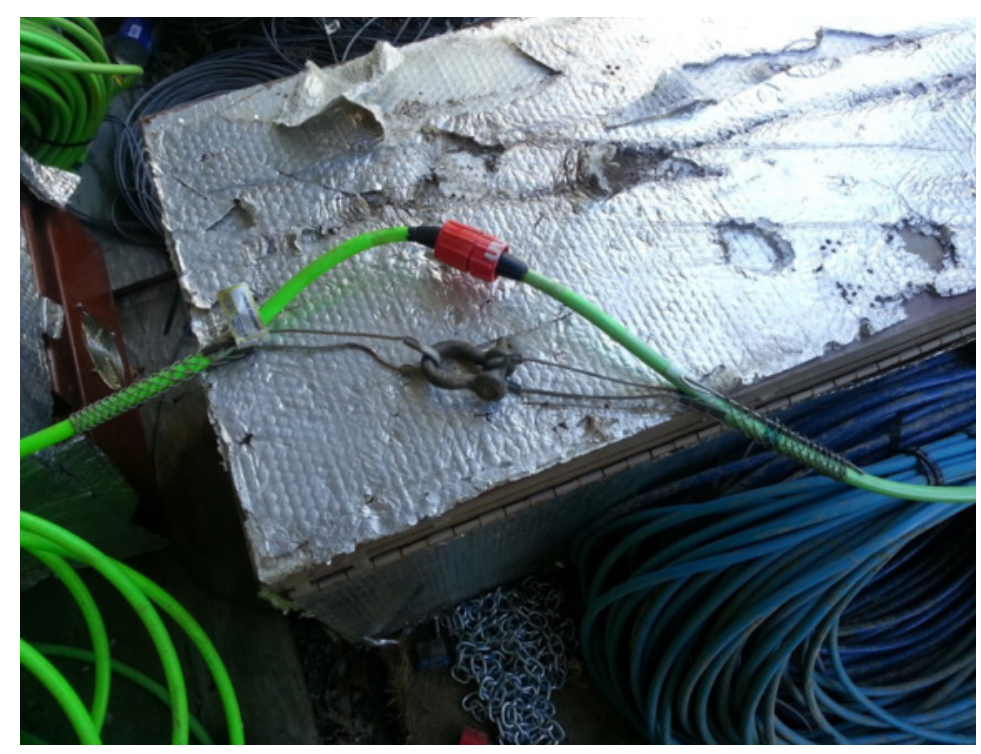

Figure 3. Photograph showing hydrophone cable connection using wire mesh cable grips and 12.7-mm shackle used in 2012. Photograph taken by Scott Evans, U.S. Geological Survey.

\section{Site-Specific Deployment}

\section{Oregon City}

The site at Oregon City, Oregon, was installed on October 3, 2012, and consisted of two hydrophones and one beacon transmitter on each of four mounts (fig. 4). Each mount had a hydrophone connected to an autonomous node and a hydrophone connected to a cabled system receiver. This allowed us to compare the performance of the two types of receivers. River depth at the hydrophone locations on the day of installation ranged from 8 to $30 \mathrm{~m}$. All receiving equipment was placed on shore in a locked U.S. Geological Survey (USGS) gaging station building. Data from the beacon transmitters deployed on each mount were used to determine functionality of the receiving systems. 


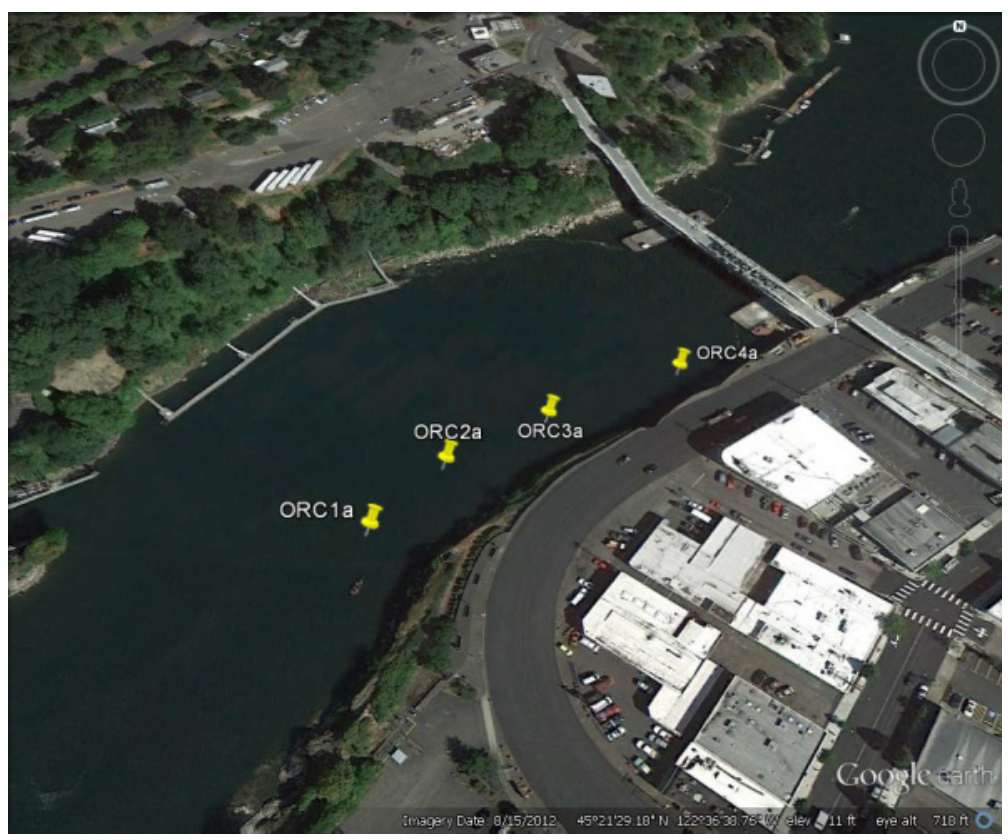

Figure 4. Schematic showing hydrophone locations installed at the Oregon City, Oregon site (river kilometer 41), 2012. 


\section{Rogue Hops Farm}

The site at the Rogue Hops Farm was installed on October 26, 2012, and consisted of one hydrophone and one beacon transmitter on each of six mounts (fig. 5). Hydrophones were placed at 50$\mathrm{m}$ intervals. River depth at the hydrophone locations on the day of installation ranged from 2.5 to $6 \mathrm{~m}$. All receivers were placed on shore in a locked steel box that was secured to a tree using 6.35-mm diameter wire rope with swaged eyes on each end attached with a lock.

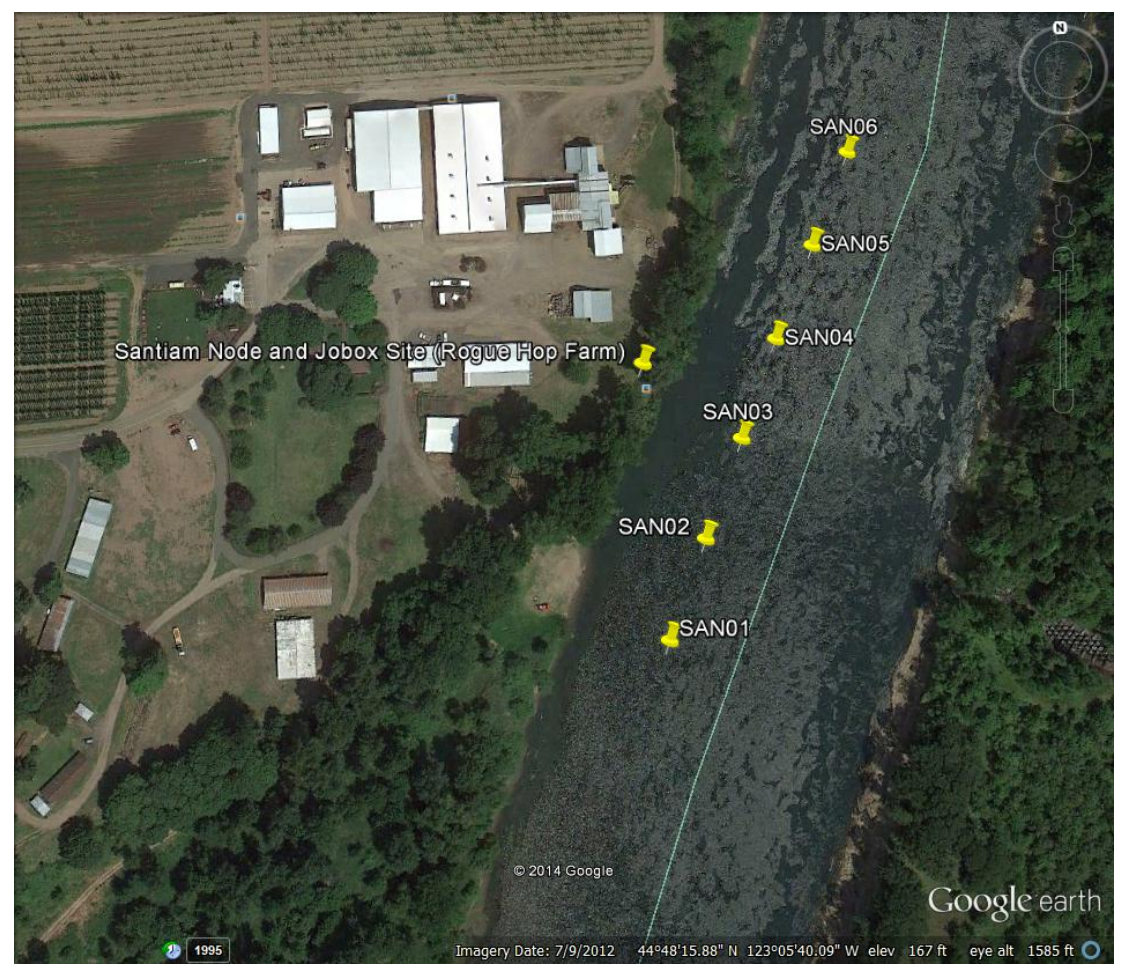

Figure 5. Schematic showing hydrophone locations at the Rogue Hops Farm site (river kilometer 165.5), Oregon, 2012. 


\section{Marshall Island Landing}

The site at Marshall Island Landing was installed on October 25, 2012, and consisted of one hydrophone and one beacon transmitter on each of six mounts (fig. 6). Hydrophones were placed approximately $50 \mathrm{~m}$ apart on the river bottom. River depth at the hydrophone locations on the day of installation was approximately $2.5 \mathrm{~m}$. All receivers were placed on shore in a locked steel box secured to a tree using $6.35 \mathrm{~mm}$ diameter wire rope with swaged eyes on each end connected with a lock.

\section{Juvenile Salmon Acoustic Telemetry System (JSATS) Tags}

Acoustic tags used in studies of juvenile salmonids in Cougar and Detroit Reservoirs in Oregon were used for the evaluation. The tags released at both locations in 2012 were manufactured by Advanced Telemetry Systems (Isanti, Minnesota), had a single model-379 battery, dimensions (mm) of 10.72 long $\times 5.22$ wide $\times 3.16$ deep, a mass $(\mathrm{g})$ of 0.31 in air, and a nominal pulse repetition interval of $16 \mathrm{~s}$. The operational life of a subset of these tags was empirically determined to be a median of $95.8 \mathrm{~d}$ and a maximum of $111.4 \mathrm{~d}$ (Beeman and others, written commun., 2014).

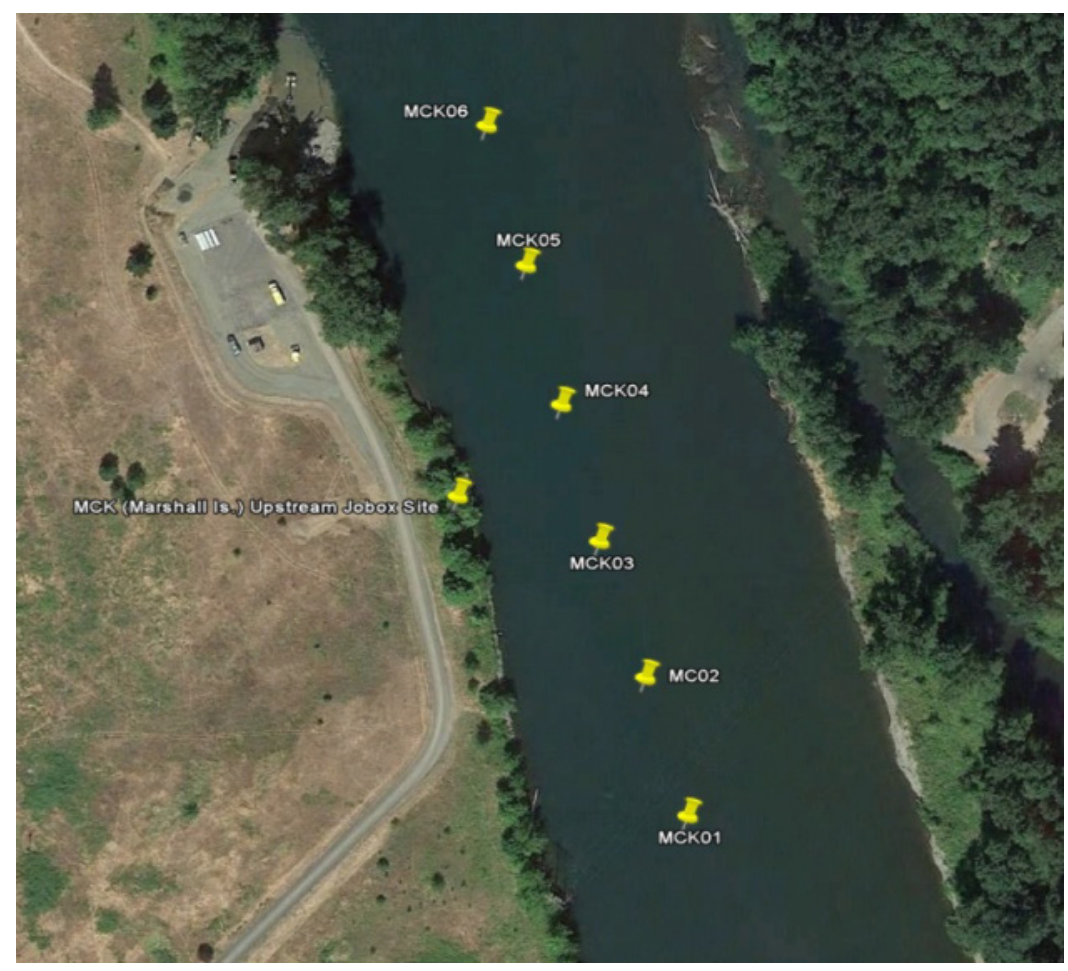

Figure 6. Schematic showing hydrophone locations at the Marshall Island Landing site (river kilometer 272), Oregon, 2012. 


\section{Results}

\section{Fish Releases in Detroit Reservoir}

A total of 514 juvenile Chinook salmon were tagged and released upstream at Detroit Reservoir from September 12, 2012, to November 28, 2012. Of the 514 Chinook salmon, 261 were released at the North Santiam River and 253 at the Breitenbush River release sites. The average fork length for Chinook salmon tagged and released on the North Santiam River was $141.8 \mathrm{~mm}$ (range 100-178 mm) and $141.6 \mathrm{~mm}$ (range 101-173 mm) on the Breitenbush River (table 1). The tag-weight-to-body-weight ratio based on the $0.41 \mathrm{~g}$ weight of the acoustic transmitter plus the PIT tag ranged from 0.6 to 3.7 percent, with an average of 1.5 percent. See Beeman and others (written commun., 2014) for detailed information about the fish released at Detroit Reservoir.

Table 1. Summary statistics of fork length (millimeters) and weight (grams) of acoustic and passive integrated transponder (PIT)-tagged hatchery Chinook salmon at Detroit Reservoir, Oregon, fall 2012.

[Release site: Indicates the location were fish were released: SAN, North Santiam River and BRE, Breitenbush River. N, number of fish, SD, standard deviation]

\begin{tabular}{|c|c|c|c|c|c|c|c|c|}
\hline & \multirow{2}{*}{$\begin{array}{l}\text { Release } \\
\text { site }\end{array}$} & \multirow[b]{2}{*}{$N$} & \multicolumn{3}{|c|}{ Fork length } & \multicolumn{3}{|c|}{ Weight } \\
\hline & & & Mean & SD & Range & Mean & SD & Range \\
\hline \multirow{2}{*}{ Fall Chinook Salmon } & SAN & 261 & 141.8 & 14.0 & $100-178$ & 30.6 & 9.9 & $13.1-63.1$ \\
\hline & BRE & 253 & 141.6 & 12.8 & $101-173$ & 30.1 & 8.6 & $11.1-56.8$ \\
\hline
\end{tabular}

\section{Fish Releases in Cougar Reservoir}

A total of 514 juvenile Chinook salmon were tagged and released from September 12, 2012, to November 28, 2012. Of the 514 Chinook salmon, 449 were hatchery reared and 65 were wild (caught from within the reservoir). The average fork length was $147.7 \mathrm{~mm}$ (range 98-180 mm) for hatchery fish and $120.8 \mathrm{~mm}$ (range 98-159 mm) for wild fish (table 2). The tag-weight-to-body-weight ratio based on the $0.41 \mathrm{~g}$ weight of the acoustic transmitter plus the PIT tag ranged from 0.6 to 3.7 percent with an average of 1.5 percent. See Beeman and others (written commun., 2014) for detailed information about the fish released at Cougar Reservoir.

Table 2. Summary statistics of fork length (millimeters) and weight (grams) of acoustic and passive integrated transponder (PIT)-tagged hatchery and wild Chinook salmon at Cougar Reservoir, Oregon, fall 2012.

[N, number of fish; SD, standard deviation]

\begin{tabular}{|c|c|c|c|c|c|c|c|c|}
\hline & \multirow[t]{2}{*}{ Source } & \multicolumn{4}{|c|}{ Fork length } & \multicolumn{3}{|c|}{ Weight } \\
\hline & & $N$ & Mean & SD & Range & Mean & SD & Range \\
\hline \multirow{2}{*}{ Fall Chinook Salmon } & Hatchery & 449 & 147.72 & 14.14 & 98-180 & 34.43 & 10.37 & $9.9-67.8$ \\
\hline & Wild & 65 & 120.83 & 10.98 & 98-159 & 19.72 & 6.22 & $9.1-6.6$ \\
\hline
\end{tabular}




\section{Environmental Conditions}

The daily river discharges during the deployment period exceeded those of the previous 68 years. Graphs of the daily average discharges near each site are in figures 7-9. The instantaneous discharge during the period of deployment, measured at 15-min intervals, ranged from 8,000 to 14,000 $\mathrm{ft}^{3} / \mathrm{s}$ near the Oregon City site, 5,500-10,800 $\mathrm{ft}^{3} / \mathrm{s}$ near the Rogue Hops Farm site, and 5,000-10,500 $\mathrm{ft}^{3} / \mathrm{s}$ near the Marshall Island Landing site. The estimated water velocities at the Rogue Hops Farm and Marshall Island Landing sites were approximately $1 \mathrm{~m} / \mathrm{s}$, based on published discharge and travel-time relations (Harris, 1968). River flow substantially increased beginning in late October.

\section{Impacts of High River Flow on Monitoring Equipment}

The increase in water volume that occurred in late October, and the corresponding debris load, proved to be more than the deployment design could withstand. The selected sites proved to be too exposed to the large volume of debris (root wads and trees) moving downstream. These pieces of large woody debris became ensnared in our cable systems and were responsible for most of the damage that was sustained by the hydrophones and cables.

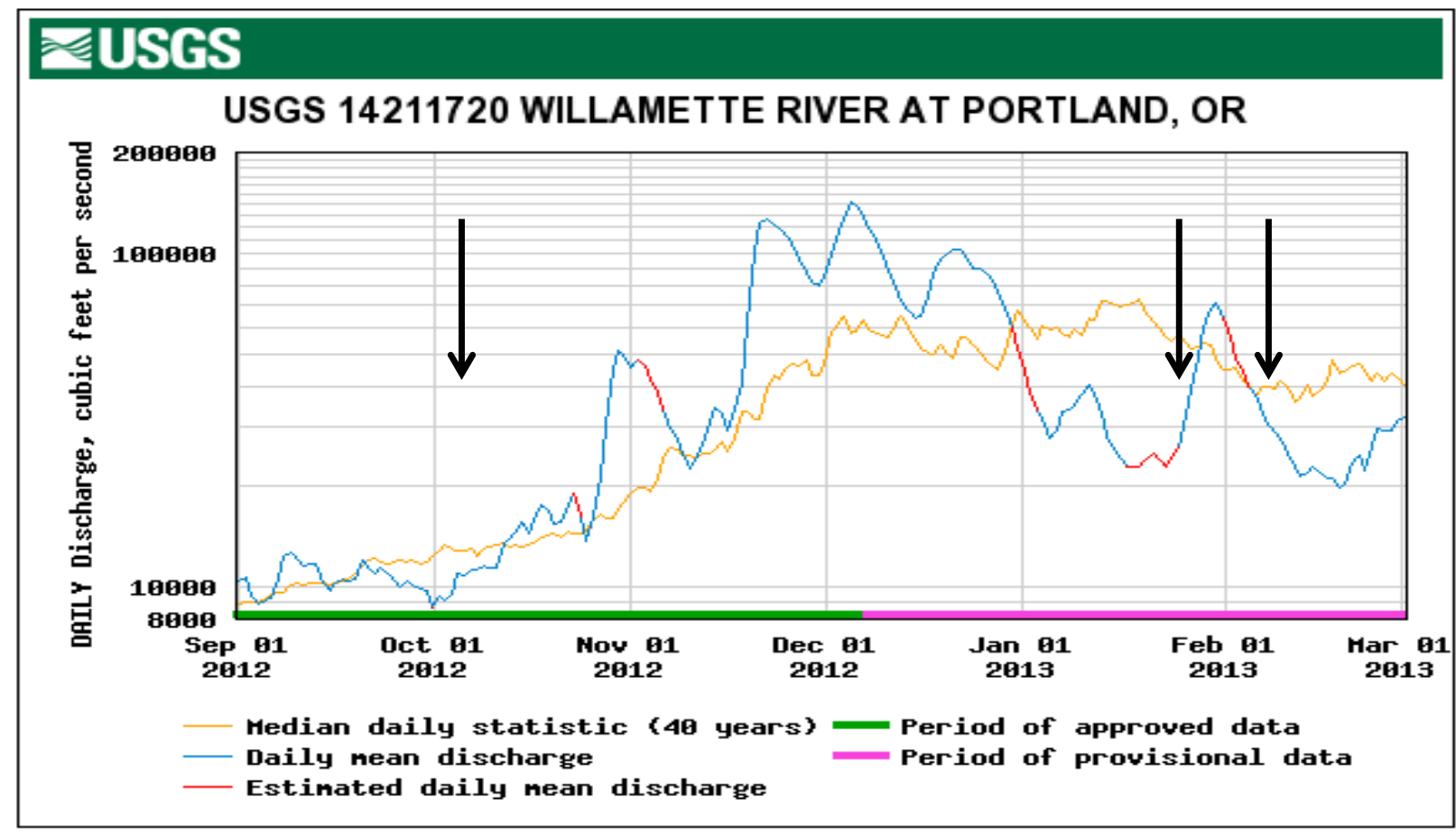

Figure 7. Hydrograph showing Willamette River discharge near the Oregon City, Oregon site. Arrows denote (from left to right) approximate dates of equipment deployment, decreased beacon tag detections, and attempted retrieval of equipment. Data from Morrison Street Bridge streamgage, located at river kilometer 20.6 (U.S. Geological Survey, 2012). 


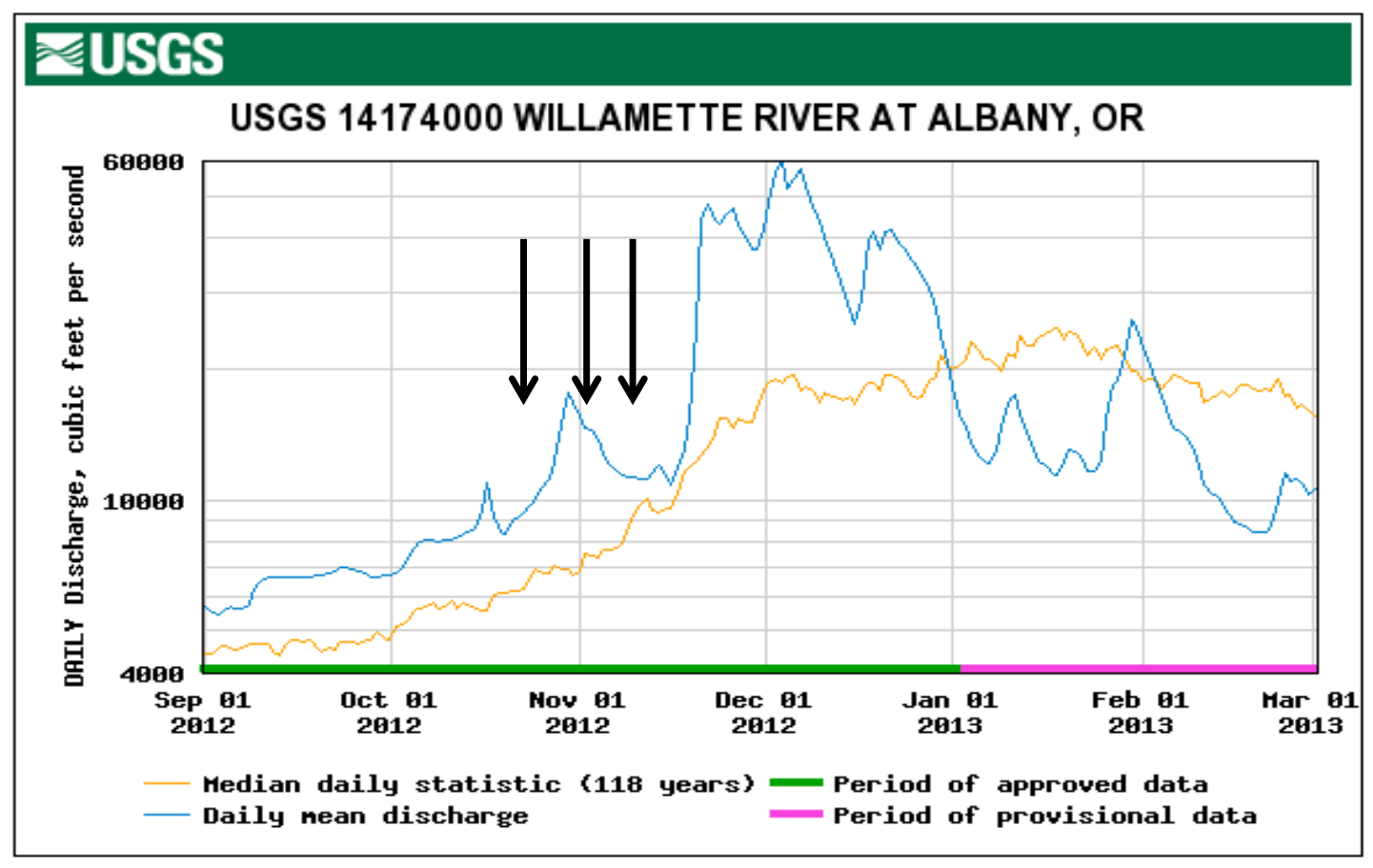

Figure 8. Hydrograph showing Willamette River discharge near the Rogue Hops Farm site. Arrows denote (from left to right) approximate dates of equipment deployment, decreased beacon tag detections, and attempted retrieval of equipment. Data from the Albany River streamgage located at river kilometer 192 (U.S. Geological Survey, 2012). 


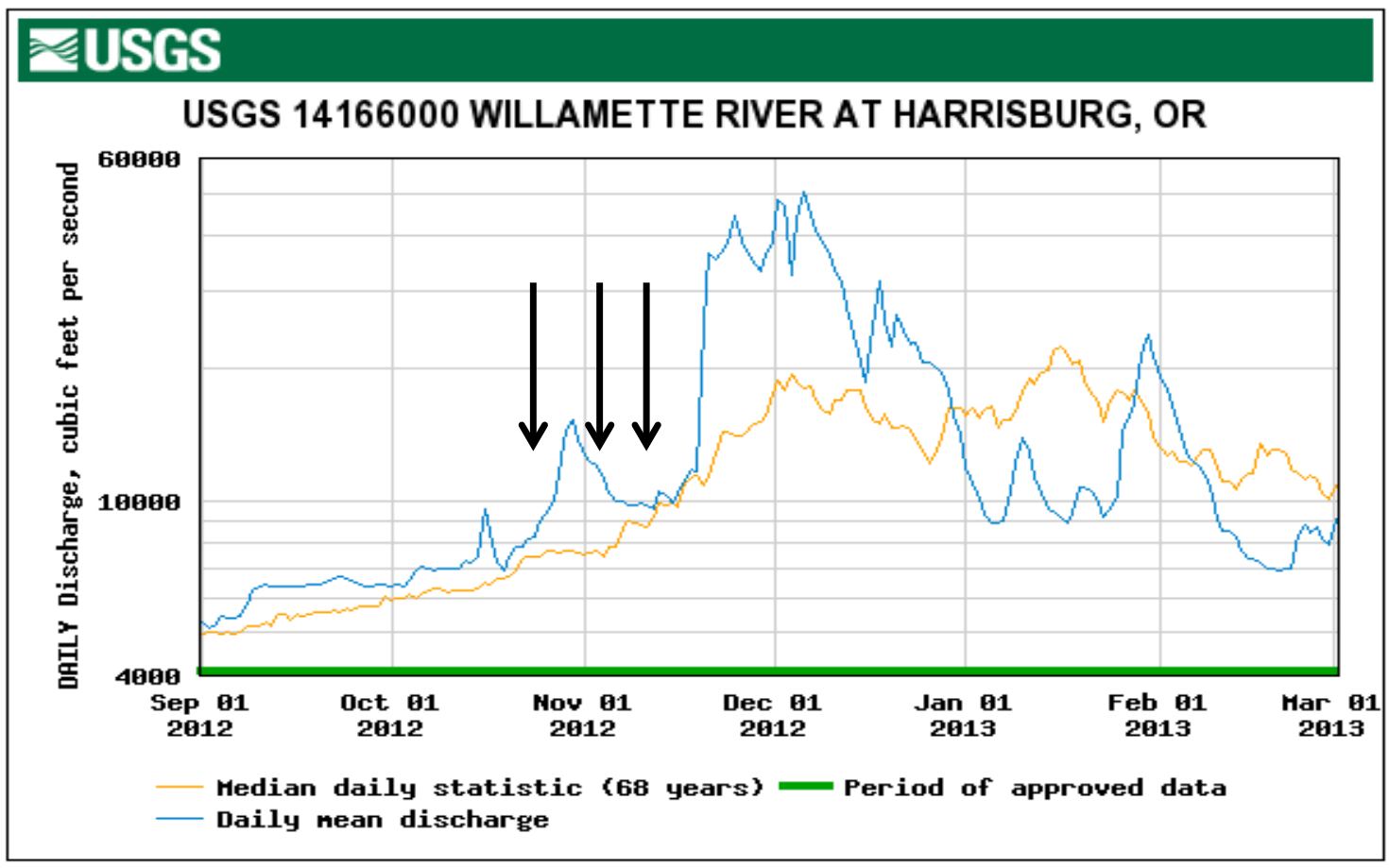

Figure 9. Hydrograph showing Willamette River discharges near the Marshall Island Landing site. Arrows denote (from left to right) approximate dates of equipment deployment, decreased beacon tag detections, and attempted retrieval of equipment. Data from the Harrisburg River streamgage located at river kilometer 259 (U.S. Geological Survey, 2012).

The Rogue Hop Farm and Marshall Island Landing sites were visited in early November. Field crew members found that the hydrophones were no longer recording beacon tag data. Both sites were visited again the following week in an attempt to remove the equipment and determine the cause of equipment failure. In trying to remove the equipment, it was discovered that the strain reliefs between cables had failed and that cables had become disconnected or their ends had broken off. Additionally, many of the hydrophones had been damaged by the high flows. Damage to the hydrophones was likely caused by the concrete block tumbling along the bottom of the river or by large pieces of woody debris striking the hydrophone tips.

The Oregon City site received data from the beacon tags through January 23, 2013. We attempted to remove the equipment from this site on February 6, 2013, but cables were stuck and river flows were too high to safely continue with the recovery effort. Most of the equipment was recovered on September 18, 2013. All but one mount was recovered and two hydrophones and two cables remained stuck on the bottom. 


\section{Travel Time}

No detections of fish were recorded at the Marshall Island Landing and Rogue Hop Farm sites. As a result, only data from the Oregon City site was used to determine travel times. Data from both the autonomous nodes and the cabled array at the Oregon City site were combined to estimate travel time from the last detection at Detroit or Cougar Dams to the first detection at Oregon City. Data were analyzed using the Kaplan-Meier Survival Analysis. A total of 49 fish were detected at the Oregon City site. Most of these fish $(\mathrm{N}=33)$ were Chinook salmon released into Cougar Reservoir, of which 32 were hatchery Chinook salmon and 1 was a wild Chinook salmon. The remaining 16 fish consisted of 13 Chinook salmon released into Detroit Reservoir, of which 5 were released in to the Breitenbush River and 8 were released in to the North Fork of the Santiam River. The median travel time from to Oregon City was 3.9 d from Cougar Dam and $4.1 \mathrm{~d}$ from Detroit Dam (fig. 10).

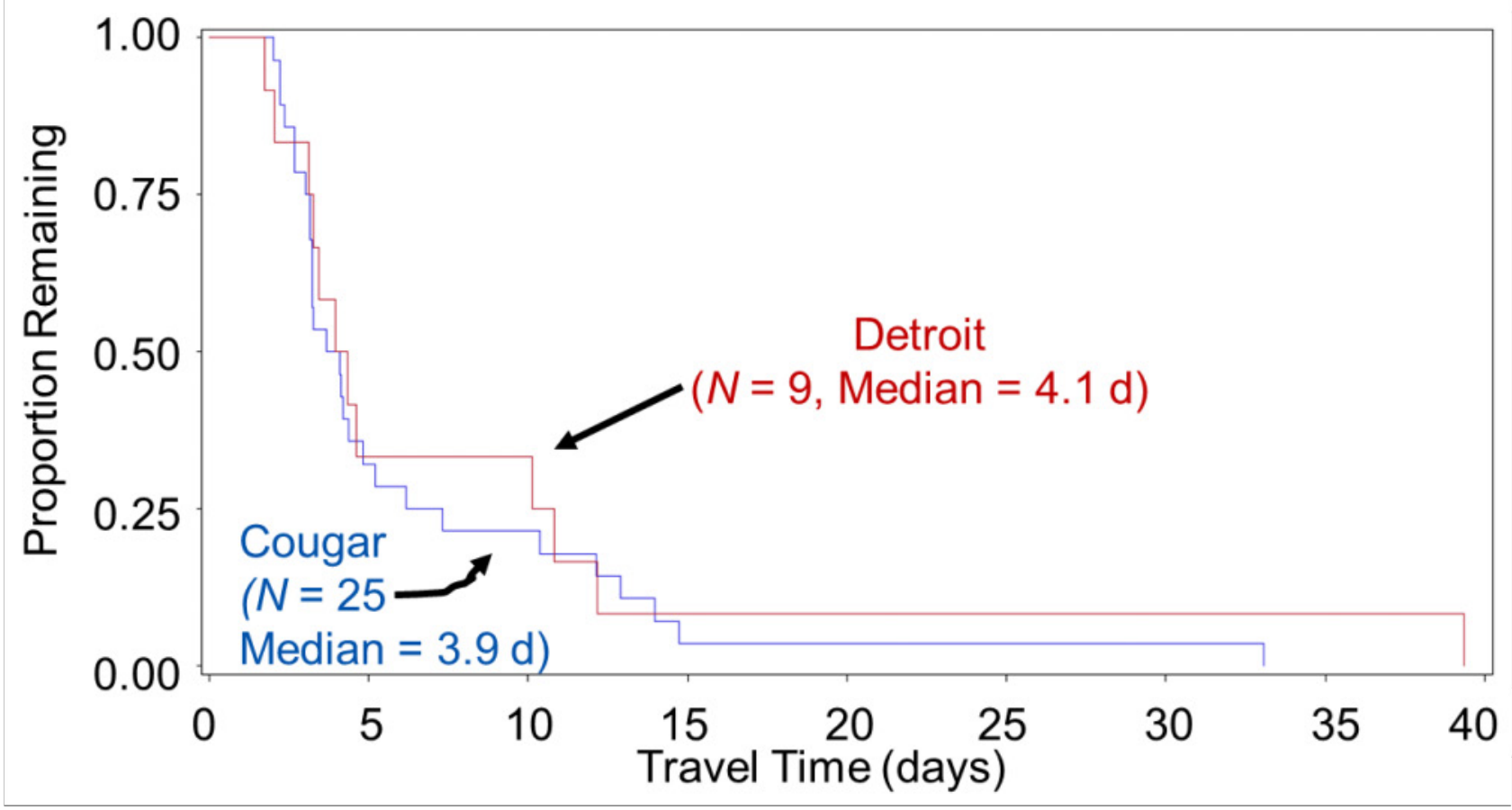

Figure 10. Graph showing travel time (in days) from the last reservoir detection to the first detection at the Oregon City monitoring site, Oregon, 2012. 


\section{Discussion}

This was a pilot study to test the efficacy of using JSATS telemetry systems in a swift, relatively shallow, riverine environment. Our first choice of deployment methods for the Willamette River was to install piles into the riverbed and affix the hydrophones to the piles. The cable from the hydrophone would run a short distance up the pile to a receiver platform atop the pile. We used this type of deployment successfully in the Columbia and Sacramento Rivers. However, owing to the short timeline for deployment and concerns that the piles would pose a hazard to other river users, an alternative deployment was used. We successfully implemented the pile method in previous studies in the Columbia, Snake, Sacramento, and Cowlitz Rivers to monitor fish movements using acoustic telemetry. The intent of this study was to determine if acoustic telemetry could be used successfully in the Willamette River. While river discharge was less than about $10,000 \mathrm{ft}^{3} / \mathrm{s}$, the deployment methods were successful. However, when discharge exceeded about 10,000 $\mathrm{ft}^{3} / \mathrm{s}$, the concrete blocks used to anchor the hydrophone mounts became dislodged, woody debris entangled the cables leading from the hydrophones to the shore, and the entire system was dragged downstream. Although monitoring site locations were selected to minimize the risk for damaged equipment, the deployment method used left the equipment unprotected when flows were relatively high. When flows were less than $10,000 \mathrm{ft}^{3} / \mathrm{s}$, the JSATS system functioned adequately in the relatively shallow and swift waters of the Willamette River. The relatively small amount of data that was collected at the Oregon City site indicated that using multiple autonomous nodes as one collective detection site is a feasible strategy for monitoring the movements of tagged fish as they migrate through the Willamette River. Future deployment designs will better protect the telemetry equipment from high flows and will enable us to evaluate the functionality of the JSATS system in high-flow environments.

\section{Alternative Deployment Methods}

The failure of the arrays at the Marshall Island Landing and Rogue Hop Farm sites, as well as the loss of some of the equipment at the Oregon City site, indicated that the methods were not appropriate for the velocity and debris loads of the Willamette River. We continued evaluating other sites throughout the season and determined that locating hydrophones directly behind bridge columns would protect the hydrophones (fig. 11). This type of installation also would offer the advantage of protecting the cable between the hydrophone to the receiver platform on the bridge (fig. 12). The location and number of bridges across the Willamette River appear to be adequate to monitor the movements of fish migrating from the McKenzie and Santiam Rivers to the mouth of the Willamette River.

Preliminary testing at the Union Street Bridge in Salem, Oregon, indicated that the bridge column method has promise. A hydrophone suspended from the bridge, directly behind a bridge column, moved very little in the current owing to the hydraulic conditions immediately downstream of the bridge column. The detection range of the hydrophone appeared to be adequate for monitoring the movements of tagged fish. Based on these preliminary results, we plan to install monitoring equipment at a number of bridges in the Salem, Wilsonville, and Portland areas in 2013. 


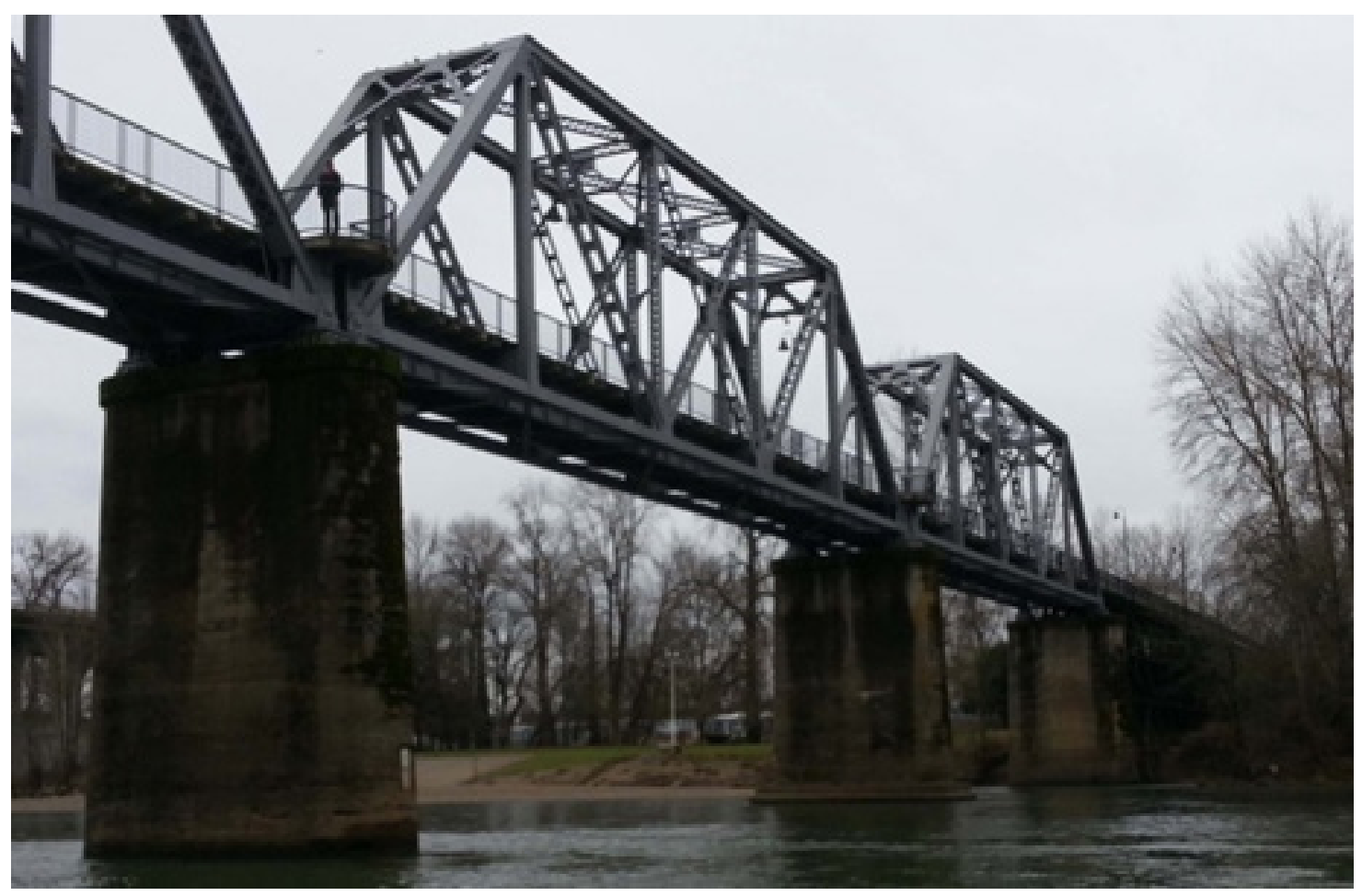

Figure 11. Photograph of Union Street Bridge in Salem, Oregon, 2012. This is an example of the types of bridges crossing the Willamette River that can be used to mount Juvenile Salmon Acoustic Telemetry System (JSATS) monitoring equipment. Photograph taken by Matthew Sholtis, U.S. Geological Survey. 


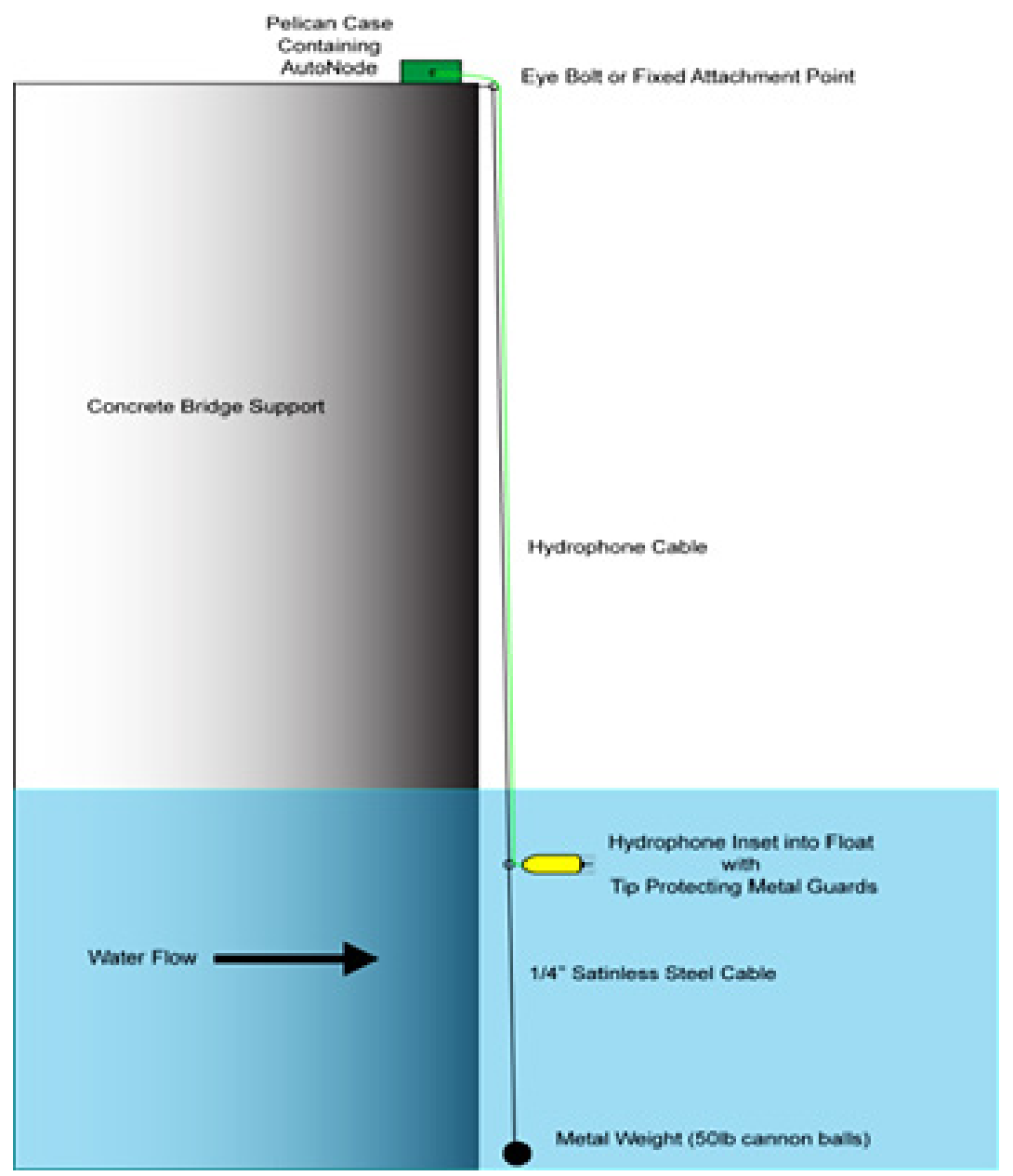

Figure 12. Schematic showing a cross sectional view of a bridge support with proposed installation of monitoring equipment. 


\section{References Cited}

Adams, N.S., Beeman, J.W., and Eiler, J.H., eds., 2012, Telemetry techniques—A user guide for fisheries research: Bethesda, Maryland, American Fisheries Society.

Beeman, J.W., and Perry, R.W., 2012, Bias from false-positive detections and strategies for their removal in studies using telemetry, in Adams, N.S., Beeman, J.W., and Eiler, J.H., eds., Telemetry techniques-A user guide for fisheries research: Bethesda, Maryland, American Fisheries Society, p. 505-518.

Burnham, K.P., Anderson, D.R., White, G.C., Brownie, C., and Pollock, K.H., 1987, Design and analysis methods for fish survival experiments based on release-recapture: American Fisheries Society, America Fisheries Society Monograph V.

Clements, S., Jepsen, D., Karnowski, M., and Schreck, C.B., 2005, Optimization of an acoustic telemetry array for detecting transmitter-implanted fish: North American Journal of Fisheries Management, v. 25, p. 429-436.

Harris, D.D., 1968, Travel rates of water for selected streams in the Willamette River Basin, Oregon: U.S. Geological Survey Hydrologic Investigations Atlas HA-273, 2 sheets.

McMichael, G.A., Eppard, M.B., Carlson, T.J., Carter, J.A., Ebberts, B.D., Brown, R.S., Weiland, M., Ploskey, G.R., Harnish, R.A., and Deng, Z.D, 2010, The Juvenile Salmon Acoustic Telemetry System-A new tool: Fisheries, v. 35, p. 9-22.

Perry, R.W., Skalski, J.R., Brandes, P.L., Sandstrom, P.T., Klimley, A.P., Ammann, A., and McFarlane, B., 2010, Estimating survival and migration route probabilities of juvenile Chinook salmon in the Sacramento-San Joaquin River delta: North American Journal of Fisheries Management, v. 30, p. 142-156.

Pincock, D.G., and Johnston, S.V., 2012, Acoustic telemetry overview, in Adams, N.S., Beeman, J.W., and Eiler, J.H., eds., Telemetry techniques-A user guide for fisheries research: Bethesda, Maryland, American Fisheries Society, p. 305-338.

U.S. Geological Survey, 2012, National Water Information System (NWISWeb): U.S. Geological Survey database, accessed on April 5, 2013, at http://waterdata.usgs.gov/nwis/.

Williams, J.G., Smith, S.G., and Muir, W D., 2001, Survival estimates for downstream migrant yearling juvenile salmonids through the Snake and Columbia rivers hydropower system, 1966-1980 and 19931999: North American Journal of Fisheries Management, v. 21, p. 310-317. 
This page left intentionally blank 
Publishing support provided by the U.S. Geological Survey Publishing Network, Tacoma Publishing Service Center

For additional information contact:

Director, Western Fisheries Research Center

U.S. Geological Survey

6505 NE 65th Street

Seattle, Washington 98115

http://wfrc.usgs.gov/ 


\section{芯}

กิ

幽

咅 